IIUC STUDIES

ISSN 1813-7733

Vol.- 7, December 2010

(Published in December 2011) (p 283-296)

\title{
Revisiting English Language Teaching (ELT) Curriculum Design: How Appropriate is Bangladesh Higher Secondary Level National ELT Curriculum as a Learner-Centred One?
}

\author{
Md. Maksud Ali*
}

\begin{abstract}
ELT curriculum design has seen several transformations overtime, especially with the changing views on the educational ideologies and philosophies in the western world. As far as teaching English in an English as a Second/Foreign language (ESL/EFL) context is concerned, it is often suggested that the ESL or the EFL education should be acculturalized as to be responsive to a particular group of people, and that again refers to the need for a national curriculum for ELT in an EFL country. Thus, in designing an ELT curriculum in an ESOL ${ }^{i}$ context, the designers need to examine not only whether the curriculum is responsive to the needs of a group of learners but also if it is 'culturally appropriate' in that context or not. Following a qualitative case study research method, this paper examines the extent to which the Higher Secondary ELT national curriculum in Bangladesh is responsive to the socio-cultural needs and the needs of the learners.
\end{abstract}

Key Words: National Curriculum; Learner-centred Curriculum; ESOL Context; Coherent Curriculum; Collaborative Approach.

\section{Introduction}

In this paper, first of all, we review the factors and different theories that underlie and shape an ELT curriculum. Then, we examine the need for a national curriculum in teaching English in an ESOL context. It should be noted here that we emphasize for a national ELT

\footnotetext{
* Lecturer (Adjunct Faculty), Department of English Language \& Literature, IIUC.
} 
curriculum so that it is socio-culturally appropriate for a group of $\mathrm{ESL} / \mathrm{EFL}$ learners, at the same time referring to the significance that the curriculum should be learner-centred, truly reflecting the needs of the learners. It is also important to note that the curriculum should have an ongoing evaluation phase that helps to evaluate the different stages of the curriculum in relation to the learners' needs on a continuous basis.

The present study relates to the Higher Secondary Education (HSE ${ }^{\mathrm{ii}}$ ) level Bangladesh national ELT curriculum, fostering a two-fold aims: (a) to examine whether the HSE ELT curriculum is socio-culturally appropriate; (b) to investigate the extent to which the curriculum is learner-centred.

\section{Literature Review}

\subsection{Language Curriculum}

Curriculum $^{\text {iii }}$ is a wide-ranging term (See for example, Allen, 1984; Candlin, 1984; Ullmann, 1982) which includes the entire 'social' 'philosophical' and 'administrative' issues in a language programme (Allen, 1984: 61). According to Nunan (1988a:8), a curriculum is associated with the planning, implementation and evaluation of a language course.

To Johnson the following four steps are important in constructing a coherent curriculum:

- curriculum planning

- ends/means specification

- programme implementation

- classroom implementation

\begin{tabular}{|c|c|c|}
\hline Developmental Stages & Decision-Making Roles & Products \\
\hline 1. Curriculum planning & Policy makers & Policy document \\
\hline \multirow{2}{*}{$\begin{array}{l}\text { Ends } \\
\text { 2. Specification: } \\
\text { Means }\end{array}$} & Need analysts & \multirow[b]{2}{*}{ Syllabus } \\
\hline & Methodologists & \\
\hline \multirow{2}{*}{$\begin{array}{l}\text { 3. Programme } \\
\text { implementation }\end{array}$} & Materials writers & $\begin{array}{l}\text { Teaching } \\
\text { materials }\end{array}$ \\
\hline & Teacher trainers & Teacher training \\
\hline
\end{tabular}


Revisiting English Language Teaching (ELT) Curriculum Design: How Appropriate is Bangladesh Higher Secondary Level National ELT Curriculum as a Learner-Centred One?

\begin{tabular}{|l|l|l|}
\hline \multirow{2}{*}{$\begin{array}{l}\text { 4. Classroom } \\
\text { implementation }\end{array}$} & Teachers & Teaching acts \\
\cline { 2 - 3 } & Learners & Learning acts \\
\hline
\end{tabular}

Table1: Stages, decision-making roles and products in curriculum development. (Source: Thomas, 2005).

\subsection{Issues Underlying a Language Curriculum}

In planning a language curriculum three chief questions arise which are; 'what to teach?' 'How to teach?' and how to 'evaluate'? (Garcia, 1976:2). However, in doing so traditionally language curriculum designers have isolated themselves from one another by focusing either on syllabus design or, methodology or, evaluation (Nunan, 1988a:3) even though in a 'consistent curriculum' decisions stemming from different phases of development should be mutually 'consistent and complementary' (Johnson, 1994: Xiii). Such a 'fragmented' view of curriculum development began to be criticized with the emergence of such questions as: to what extent are the 'content' and 'methodology' consistent and useful? (See for example, Breen and Candlin, 1980:89). However, the shift from a fragmented approach to a 'collaborative effort' to design a 'learner-centred curriculum' (see, Nunan, 1988b) is the result of a long historical debate on educational philosophies, to be discussed below.

\subsection{Language Curriculum: Philosophies that Shape it}

Language curriculum design has undergone several changes with numerous philosophical and theoretical assumptions. The traditional approach to curriculum design is guided by the philosophy of what White (1988:24) calls the 'Classical humanism' or the 'Cultural transmission', a philosophy of education in which the teacher is seen as a transmitter of information, rules and values. (Pope \& Keen, 1981). 'Classical humanism' encourages Grammar Translation Method in language teaching.

Eventually, with the changing views in the educational ideologies, the 'Reconstructionism', 'a philosophy underpinning the ends- means, or objectives, approach to curriculum design' (Nunan, 1988b:16), appears as a reaction to the 'Classical humanism' (White, 1988). However, the 'Reconstructionism' itself leads to the design of an exclusively 'product-oriented' curriculum (Nunan, 1988b) which encourages a 'one-size-fits-all approach' in language teaching (Long, 2005: 1). As for the teaching methodology, this philosophy upholds the 'Audio-lingual Method' (White, 1988) in which language 
education takes a 'subject-centric' view of teaching and learning (Nunan, 1988b:16), largely drawing upon 'structural linguistics' stemming from the theory of 'Behaviourism' (Richards \& Rodgers 1986; Richard, 2001).

However, Hymes' (1971) rejection of Chomsky's (1965) 'Linguistic Competence' and his proposal of the 'Communicative Competence' to show the use of language in a 'social context' (also see, Nunan, 2001:16), paved the way for a more comprehensive view in language education. As a result, 'Progressivism' appears as an alternative view to replace 'Classical humanism' and 'Reconstructionism', encouraging a 'learner-centred curriculum' for language education (Nunan, 1988b). Progressivism is a philosophy of education that stimulates learning relating it to 'real-life situations' and involving the 'perceptions' of the learners (Crawford-Lange in White, 1988). With the shift from a 'product' based curriculum to what Wette (2010) terms as a 'processoriented curriculum', there was also a shift in methodology towards 'Communicative Language Teaching'(CLT) which became widely popular in the ESL education during 1980s. (Jacobs \& Farwell, 2001 \& 2003).

Having discussed the philosophical basis to curriculum design, the following sub-section examines some of the important aspects of a learner-centred curriculum theory.

2.4 Revisiting a Learner-Centred Curriculum: Theory for Practice As indicated in section 2.1, curriculum is essentially concerned with the process of planning, implementation and evaluation of a language program. In this process, however, it is important that all elements be integrated so that decisions made at one level are not in conflict with those at another (Nunan, 1988a:5). Such an emphasis on an 'integrated approach' (Thomas, 2005) led to a more systematic and 'learnercentred' approach where curriculum is viewed as a 'cyclical process of development, revision, maintenance and renewal which need to continue throughout the life of the curriculum' (Johnson, 1994).

In a 'learner-centred' approach to curriculum design, the 'initial step' (Yalden, 1983:101) and the 'fundamental principles' (Brindley, 1989:63) are the analysis of the learners' needs, indicating that learners' are 'central' 'to all aspects of language teaching, including planning, teaching and evaluation' (Richard \& Schmidt, 2002:197-8). Once learners' needs are analysed, the findings from the needs analysis 
will help the curriculum designers to determine the course aims, syllabus contents, materials and methods (Nunan, 1988b:6). It is important that the needs analysis process be on-going because the most important information relating to the learners' 'subjective needs' can be obtained only when a language program is implemented and because the information regarding the learners' objective needs from an initial needs analysis is often 'superficial' (Nunan, 1988b).

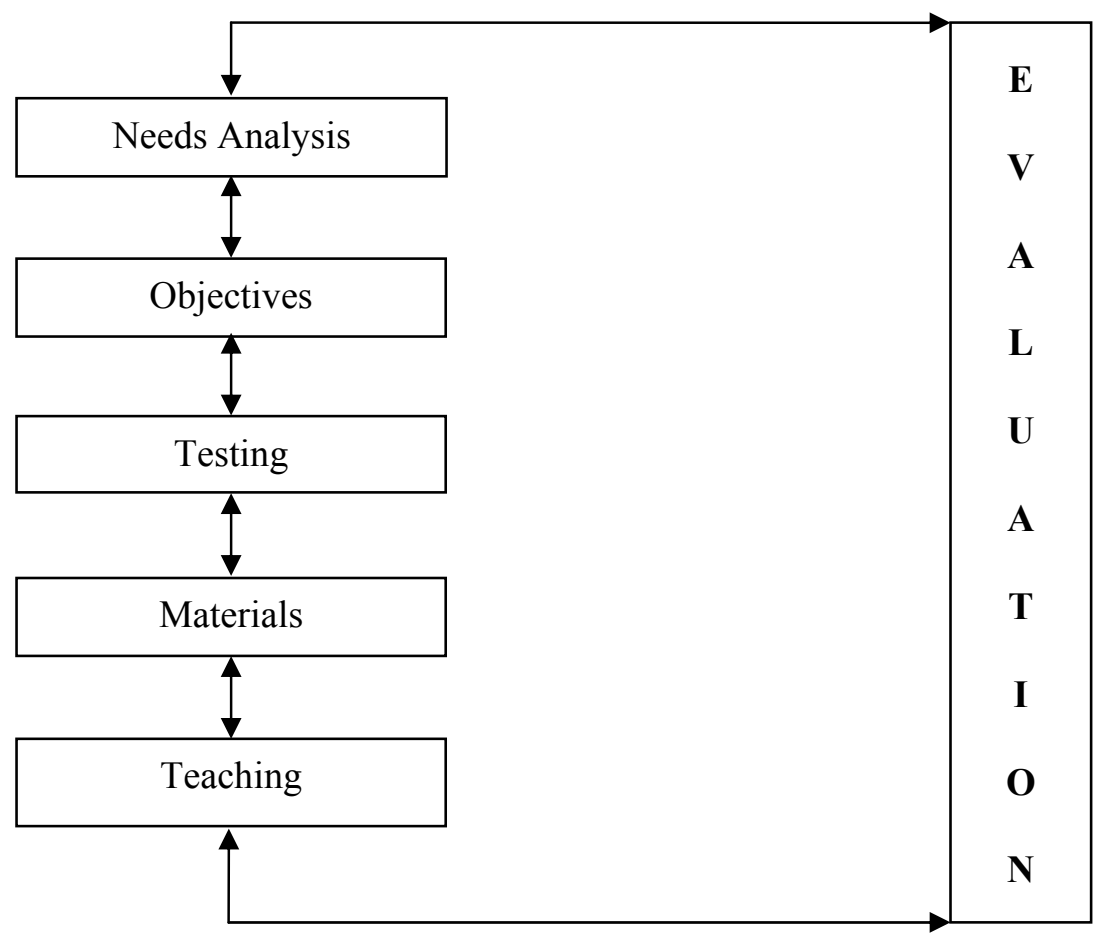

Figure (1): Systematic Curriculum Model. (Source: Brown, 1995:20).

A learner-centred curriculum needs to have a sound Program evaluation section. It is important because it '...promotes the improvement of the curriculum...assesses its effectiveness within the context of the particular situations involved' (Brown, 1995:24). According to Kiely (2006:597), evaluation is a 'byword' for innovation. Markee (1997:47) posits that 'innovation is a species of the genus change in which change is an ongoing process'. Evaluation may be at different stages of a given curriculum (see for example, Allen, 1984:73; Ur, 1991:194; Richard, 2001:256, Johnson, 1994; Markee, 1997). Brown's (1995) systematic 
curriculum model may be used for the purpose of evaluation at different stages of curriculum (see figure 1).

\subsection{Importance of a National Curriculum}

A national curriculum is vital in teaching English in an ESL/EFL context. In an ESOL context, for example, in teaching English to speakers of other languages (TESOL), 'it is apparent that an English instruction which has not been acculturalized and shaped to fit the local needs can constitute a threat to identity' (Bamon,2004). Bamon claims, to resist the 'threat of being de-ethnified and de-culturalized' people should have 'local identity'.

The objectives in a national curriculum help 'develop a reasoned commitment to the goals of a national development by cherishing, preserving and developing moral and spiritual values and other aspects of the national heritage...'(Garcia, 1976). A curriculum, according to Yalden (1984), is a 'public record', 'a contact' 'an instrument' that clearly shows the 'negotiation' amongst all the parties engaged and it focuses on the 'ends of the instruction and its social purpose'. Therefore, a curriculum design has to conform to the national educational policy and language policy (Halim, 1976) and thus, 'as projections of educational policy, a curriculum and the different syllabuses within it, will conform to varying ideological decisions about the purpose and nature of education as a whole'(Widdowson, 1983).

\section{Research Design}

In this study we use an interpretive research approach leading it to a qualitative method of inquiry. A 'case study' strategy is followed as an instrument so that the HSE ELT curriculum, under review, may be examined in relation to the grounded curriculum theory discussed in the literature review section. According to Yin (2003:13), the case study is 'an empirical inquiry that investigates a contemporary phenomenon within its real-life context, especially when the boundaries between phenomenon and context are not clearly evident'.

The data for this research stem from various sources; such as, the HSE curriculum documents, HSE ELT Teacher's Guide and textbook, Bangladesh ministry of Education (MoE) website, National Curriculum and Textbook Board Bangladesh (NCTB) website, etc. To analyse the collected data and evaluate the ELT curriculum, under review, we use the grounded theory of a learner-centred curriculum 
Revisiting English Language Teaching (ELT) Curriculum Design: How Appropriate is Bangladesh Higher Secondary Level National ELT Curriculum as a Learner-Centred One?

because this strategy gives us an opportunity to compare the HSE ELT curriculum with the theory in the literature. Grounded theory which refers to "the discovery of theory from data" (Glaser \& Strauss, 1967:1) gives the researcher a chance to theorise from evidence existing in the data.

\subsection{Research questions}

For the purpose of this project, we aim at addressing the following research questions:

1. Does the HSE English language teaching curriculum in Bangladesh bear national socio-cultural identity?

2. To what extent is the HSE ELT curriculum learner-centred?

Before addressing the research questions, it is necessary to examine the overall aims of the HSE English course in order to put the research in context.

\subsection{Research context}

The overall objectives of the Higher Secondary level English language program are to help the HSE level students develop their four English language skills (i.e., reading, writing, listening and speaking). At HSE, it is expected that the learners will acquire the skills by 'actually' 'practising those skills rather than merely listening to the teacher' (see, Teachers' Guide). Three 'central' aims of the program are to:

1. 'increase learner motivation by raising awareness that what they are learning is the language of the real world and is therefore useful to them'.

2. 'help the learners communicate in a wide range of interesting situations'.

3. 'help develop the learners' speaking, listening, reading and writing skills so that they can communicate accurately and appropriately'.

(Source: Shahidullah, e. al., 2007. Teacher's Guide).

The HSE English language national curriculum of Bangladesh suggests a learner-centred language education. With the shift from a traditional grammar based language education to the communicative competence based language education, the curriculum now nourishes the philosophy that language education is not a product of mere classroom instruction, rather is a process that is stimulated by the 
analysis of the learners' needs (cf., the preface of the HSE English textbook).

This study, therefore, aims at investigating the extent to which the curriculum, under review is responsive to the needs of the learners as the program and the curriculum identify themselves to be the proponents of a learner-centred education.

\section{Data Analysis and Discussion}

\subsection{Research Question 1: Does the HSE English language teaching curriculum in Bangladesh bear national socio-cultural identity?}

In developing a curriculum for English as a second language classes, NCTB seems to nourish the belief of national integrity, solidarity, cultural heritage, sovereignty, culture, etc. The national ELT textbook for HSE classroom in Bangladesh have been acculturalized so that they fit with the local context (cf. English $1^{\text {st }}$ paper textbook). The textbook, as a projection of the curriculum, presents local beliefs, values, traditions and so on (idid). Moreover, it encourages an intercultural communication by introducing the learners with the international culture along with their home identity (ibid). In addition, beside preserving national spirit, NCTB is increasingly aware about the importance of considering the 'global changes' in designing the national curriculum for ESL $\left(\mathrm{NCTB}^{\mathrm{iv}}\right)$ classroom. For example, it introduces issues like world climate change, pollution, green house effects, internationally reputed celebrities, etc in the language syllabus (cf., the textbook). As a result, students may come out of an English language programme enriched by a knowledge and a love of own culture while at the same time be members of a wider global and cultural milieu.

Thus, the national curriculum of Bangladesh is developed through a sense of national spirit with the flavour of Bangladeshi socio-cultural setting rather than merely imitating Euro-centric norms. The HSE ELT national curriculum of Bangladesh, therefore, may serve not only in making the learners competent in English as a second language but also in creating a sense of socio-cultural heritage of their own motherland in the learners.

From the findings above, it may be suggested that the HSE English language teaching curriculum in Bangladesh bears the national sociocultural identity. 
Revisiting English Language Teaching (ELT) Curriculum Design: How Appropriate is Bangladesh Higher Secondary Level National ELT Curriculum as a Learner-Centred One?

\subsection{Research Question 2: To what extent is the HSE ELT curriculum learner-centred?}

As noted in 3.2, the HSE English language curriculum nourishes the philosophy of a learner-centred ESL education. A learner-centred language curriculum finds its base in the on-going analysis of the learners' needs (see section, 2.4, also see figure, 1). However, in the HSE English Language curriculum there is no needs analysis section which actually includes the learners and the teachers and their perceptions, rather learners' needs are perceived based on the 'national education policy and philosophy' (see figure,2 below) and based on the "needs of society"v .

Bangladesh national curriculum: 'Who makes which choices?'

\begin{tabular}{|c|c|c|c|}
\hline & $\begin{array}{l}\text { CENTRAL } \\
\text { LEVEL }\end{array}$ & $\begin{array}{l}\text { REGIONAL } \\
\text { LEVEL }\end{array}$ & $\begin{array}{l}\text { SCHOOL } \\
\text { LEVEL }\end{array}$ \\
\hline & $\begin{array}{l}\text { National } \\
\text { Curriculum } \\
\text { and Textbook } \\
\text { Board } \\
\text { prepares } \\
\text { curriculum } \\
\text { in light of } \\
\text { national } \\
\text { educational } \\
\text { philosophy } \\
\text { and policy; } \\
\text { Committee of } \\
\text { Ministry of } \\
\text { Education } \\
\text { subsequently } \\
\text { approves } \\
\text { Curriculum }\end{array}$ & $\begin{array}{l}\text { Local } \\
\text { authorities } \\
\text { assist with } \\
\text { curriculum } \\
\text { development } \\
\text { by providing } \\
\text { suggestions }\end{array}$ & $\begin{array}{l}\text { Teachers } \\
\text { prepare } \\
\text { lesson plans } \\
\text { based on } \\
\text { curriculum }\end{array}$ \\
\hline $\begin{array}{l}\text { CURRICULUM } \\
\text { PLAN }\end{array}$ & $\begin{array}{l}\text { Prepares } \\
\text { syllabus and } \\
\text { distribution of } \\
\text { subject } \\
\text { marks. } \\
\text { Prepares time } \\
\text { table }\end{array}$ & $\begin{array}{l}\text { Monitors the } \\
\text { implementation } \\
\text { of curriculum }\end{array}$ & $\begin{array}{l}\text { Implements the } \\
\text { curriculum } \\
\text { at the } \\
\text { classroom } \\
\text { level. }\end{array}$ \\
\hline
\end{tabular}




\begin{tabular}{|l|l|l|l|}
\hline $\begin{array}{l}\text { METHODS } \\
\text { AND } \\
\text { APPROACHES } \\
\text { TO LEARNING }\end{array}$ & $\begin{array}{l}\text { Field tests } \\
\text { and finalizes } \\
\text { the intended } \\
\text { curriculum }\end{array}$ & $\begin{array}{l}\text { Assists with } \\
\text { the finalization } \\
\text { of curriculum }\end{array}$ & $\begin{array}{l}\text { Measures } \\
\text { competency } \\
\text { attainment }\end{array}$ \\
\hline MATERIALS & $\begin{array}{l}\text { Prepares } \\
\text { teachers' } \\
\text { Guide and } \\
\text { learning } \\
\text { Materials }\end{array}$ & $\begin{array}{l}\text { Distribute } \\
\text { teachers'guide } \\
\text { and learning } \\
\text { materials }\end{array}$ & $\begin{array}{l}\text { Utilizes } \\
\text { teachers' guide } \\
\text { and learning } \\
\text { materials in the } \\
\text { classroom }\end{array}$ \\
\hline $\begin{array}{l}\text { EVALUATION } \\
\text { AND }\end{array}$ & $\begin{array}{l}\text { Prepares } \\
\text { evaluation } \\
\text { and exam } \\
\text { plans }\end{array}$ & $\begin{array}{l}\text { Implements } \\
\text { secondary level } \\
\text { examinations } \\
\text { (various } \\
\text { regional } \\
\text { boards) }\end{array}$ & $\begin{array}{l}\text { Conducts } \\
\text { terminal } \\
\text { examinations at } \\
\text { primary and } \\
\text { secondary } \\
\text { levels }\end{array}$ \\
\hline
\end{tabular}

Figure(2): Organization of Bangladesh national curriculum: 'Who makes which choices?' (Data source: Hossain \& Jahan, 2005).

The HSE ELT curriculum of Bangladesh is thus developed following a 'top-down, vi approach. Although in a learner-centred curriculum the decisions from different stakeholders should be mutually consistent and collaborative (cf., section, 2.4), in the HSE English language curriculum there seems to have no collaboration among the different stakeholders, rather the curriculum itself is planned and designed by the NCTB curriculum specialists (see figure, 2). Therefore, even though the curriculum fosters a learner-centred philosophy of 'progressivism' with a motto of implementing Communicative Language Teaching (CLT), in practice it seems to implement the philosophy of 'Reconstructionism' which in reality practices a 'Onesize-fits all' product curriculum (cf., section, 2.3).

It has also been noted in the theory of a learner-centred curriculum that a curriculum becomes consistent through a continuous process of evaluation of the curriculum at different stages (cf., figure,1 at 2.4). There is, however, no sound program evaluation phase in the HSE ELT curriculum that examines the effectiveness of different stages of the curriculum on an on-going basis; rather the curriculum exclusively confines itself to the assessment of the learners through different examination $^{\text {vii. }}$. 
Revisiting English Language Teaching (ELT) Curriculum Design: How Appropriate is Bangladesh Higher Secondary Level National ELT Curriculum as a Learner-Centred One?

\section{Implication to the Broader Theory}

In the literature review chapter, it was noted that a learner-centred curriculum finds its ground in the educational philosophy of the 'Progressivism' in which learning is related to 'real-life situations' and to the needs of the learners (cf., Section, 2 at 2.1.3).The findings of this research suggest that the theory of 'Progressivism', in other words, a learner-centred language curriculum cannot be established if its design is followed by a Top-Down approach. Additionally, this research demonstrates that a conflict may appear in a language program if the decisions stemming from different stakeholders (e. g., curriculum designers, learners, and teachers) are not integrated in the design of a curriculum (also see, Section, 2). Based on the findings in this research, it may be argued that in designing a learner-centred language curriculum, an 'integrated', 'Bottom-Up', and 'collaborative' approach should be applied so that there is not any mismatch in the curriculum while it comes to the implementation phase. In other words, a 'collaborative approach' is essential in order to make a curriculum truly learner-centred because this approach helps in the analysis of the learners' and the other stakeholders' needs on a continuous basis. And it is this negotiation that brings consistency in the design and the implementation of a learner-centred curriculum.

\section{Conclusion}

Although in designing the HSE ELT curriculum, NCTB tries to focus on national identity, in so doing however, it hardly consults the learners to observe their views on their linguistic and pedagogical needs. This mismatch between the philosophy of the curriculum and its practice is highly potential to create a mismatch between the expected outcome and the actual learning outcome from the program. We believe that to enjoy the genuine usefulness of the national curriculum, NCTB curriculum specialists, besides taking the local culture and context into consideration, also ought to incorporate the learners in curriculum design. This, I hope, will not merely make the learners innovative and creative but also prove as a wonderful tool in fulfilling the noble objectives of NCTB with the Higher Secondary ELT curriculum of Bangladesh.

In this paper, while we have examined the design of the HSE ELT national curriculum of Bangladesh, a further research may also be suggested on the implementation of the curriculum as to investigate how the design is affecting the implementation. 


\section{References}

1. ALLEN, J. P. B. (1984). General-Purpose Language Teaching: A Variable Focus Approach. In Brumfit, C. J. (Eds.), General English Syllabus Design. Pergamon Press.

2. BREEN, $M$ and CANDLIN, C. (1980). The Essentials of a Communicative Curriculum in Language Teaching. Applied Linguistic Journal, Vol-1; No-2. Oxford.

3. BRIENDLEY, G. (1989). The role of needs analysis in adult ESL program design. In Johnson, (Eds.), The Second Language Curriculum. Cambridge University Press.

4. BROWN, J. D. (1995). The Elements of Language Curriculum: A Systematic Approach to Program Development. Heinle and Heinle.

5. BAMON, T. K. (2004). The English Text: Establishing Identity .IATEFL Newsletter. newsletter/TheEnglishText.pdf

6. CANDLIN, C. N. (1984). Syllabus Design as a Critical Process. In Brumfit, C. J. (Eds.), General English Syllabus Design: Curriculum and Syllabus Design for the General English Classroom: ELT documents 118. Pergamon Press.

7. GARCIA, D. G. (1976). Decisions and Variables in Curriculum Constructions: Their Implication for Syllabus Design in English Language Teaching. In Wilson (Eds.). Curriculum Development and Design in English Language Teaching. Singapore University Press.

8. GLASER, B. G., \& STRAUSS, A. L. (1967). The discovery of grounded theory: Strategies for qualitative research. Chicago: Aldine.

9. HYMES, D. (1972). On Communicative Competence. In Pride. J. B and Holmes, J. (Eds.), Sociolinguistics. Harmondsworth. Penguin.

10. HALIM, A. (1976). Decision-Making in the Language Design. In Wilson, G. H. (Eds.),Curriculum Development and Syllabus Design for English Teaching. Singapore University Press.

11. HOSSAIN, M. A. and JAHAN, S. (2005). Bangladesh curriculum planning, development and reform for primary and secondary education. In Rao, D. B. (Eds.), Globalization and Living Together. UNESCO: Discovery Publishing House: Delhi, India.

12. JOHNSON, R. (1994). The Second Language Curriculum. Cambridge University Press.

13. JACOBS, G. M. and FARELL, T. S. C. (2003). Understanding and Implementing the CLT(Communicative Language Teaching) Paradigm. RELC Journal. 34(1).pp. 5-30. 
Revisiting English Language Teaching (ELT) Curriculum Design: How Appropriate is Bangladesh Higher Secondary Level National ELT Curriculum as a Learner-Centred One?

14. JACOBS, G. M. and FARELL, T. S. C. (2010). Essentials for Successful English Language Teaching. Continuum.

15. KIELY, R. (2006). Evaluation, Innovation, and Ownership in Language Program. The Modern Language Journal, Vol-90, No-4, pp. 597-601.

16. LONG. M. H. (2005). Second Language Needs Analysis. Cambridge University Press.

17. MARKEE, N. (1997). Managing Curricular Innovation. Cambridge University Press.

18. NUNAN, D. (1988a). Syllabus Design. Oxford University Press.

19. NUNAN, D. (1988b). The Learner-Centred Curriculum: A study in second language teaching. Cambridge University Press.

20. NUNAN, D. (2001). Aspects of Tasked-Based Syllabus Design. Karen's Linguistic Issues, December, 2001.

21. POPE, M. L. and KEEN, T. (1981). Personal Construct Psychology and Education. Academic Press Inc: London.

22. RICHARDS, J. C. and RODGERS, T. S. (1986). Approaches and Methods in Language Teaching : A description and analysis. Cambridge University Press.

23. RICHARD, J. C. and RODGERS, T. S. (2001). Approaches and Methods in Language Teaching. Cambridge University Press.

24. RICHARD, J. C. and SCHMIDT, R. (2002; $3^{\text {rd }}$ Edition). Longman Dictionary of Language Teaching and Applied Linguistics. London: Longman.

25. RICHARD, J. C. (2001). Curriculum Development in Language Teaching. Cambridge University Press.

26. SHAHIDULLAH, M; et. al. (2007). Teacher's Guide for English for Today: For Classes XI-XII. NCTB

27. SHAHIDULLAH, M; et. al. (2007). English for Today: For Classes 1112. NCTB

28. THOMAS, M. (2005). The Coherent Curriculum. IATEFL, April-May, 2005, Issue- 184.

29. UR, P. (1991). A Course in Language Teaching: Practice and Theory. Cambridge University Press.

30. ULLMANN, R. (1982). A broadened curriculum framework for second languages. ELT Journal; Vol-36/4.

31. WHITE, R. V. (1988). The ELT Curriculum Design, Innovation, and Management. Basil: Blackwell. Learning 
32. WIDDOWSON, H. G. (1983). Purpose and Language Use. Oxford: Oxford university Press.

33. WETTE, R. (2010). Product- process distinctions in ELT Curriculum theory and practice. ELT, Journal Advance Access published May 30, 2010; doi:10.1093/elt/ccq022.

34. YALDEN, J. (1984). Syllabus Design in General Education: Option for ELT. In Brumfit, C. J. (Eds.), General English Syllabus Design: Curriculum and Syllabus Design for the General English Classroom: ELT documents 118. Pergamon Press.

35. YIN, R. K. (2003). Case study research: Design and methods (3rd ed., Vol. 5). Thousand Oaks, CA: Sage.

\section{Endnotes}

i English to the Speakers of Other Languages.

ii We distinguish HSE from HSC in that by HSE we refer to the higher secondary education as a whole while HSC refers only to the higher secondary examination. For details, see Bangladesh Bureau of Educational Information and Statistics (BANBEIS) website at: http://www.banbeis.gov.bd/es bdhtm under the title of 'Educational structure of Bangladesh'.

iii Although in many contexts, curriculum and syllabus are used interchangeably (Epstein \& Ormiston, 2007:15), in this research syllabus and curriculum are distinguished.

iv Available at: http://www.nctb.gov.bd/article.php?cat=1\&subcat=39

$v$ Stated in Bangladesh Ministry of Education (MoE) website at www.moedu.gov.bd/

vi In curriculum designing a Top-Down approach is the one in which decisions come from the authority alone without consulting those who are actually going to implement the curriculum. In this approach curriculum or syllabus is designed by those who are actually away from the real scene where the curriculum or the syllabus is implemented. A top-down approach may be contrasted with the Bottom-up approach in which there is a collaboration among all the parties involved.

vii Here we distinguish evaluation from assessment in that by evaluation we mean the investigation of the effectiveness of the program, while assessment is used to refer to examination. 